\title{
Alain Riffaud, Répertoire dramatique du théâtre français imprimé (1630-1660)
}

\section{Monica Pavesio}

\section{Q OpenEdition}

1 Journals

\section{Edizione digitale}

URL: http://journals.openedition.org/studifrancesi/6267

DOI: 10.4000/studifrancesi.6267

ISSN: 2421-5856

\section{Editore}

Rosenberg \& Sellier

\section{Edizione cartacea}

Data di pubblicazione: 1 novembre 2010

Paginazione: 548

ISSN: 0039-2944

\section{Notizia bibliografica digitale}

Monica Pavesio, «Alain Riffaud, Répertoire dramatique du théâtre français imprimé (1630-1660)», Studi Francesi [Online], 162 (LIV | III) | 2010, online dal 30 novembre 2015, consultato il 11 janvier 2021. URL: http://journals.openedition.org/studifrancesi/6267 ; DOI: https://doi.org/10.4000/studifrancesi.6267

Questo documento è stato generato automaticamente il 11 janvier 2021.

\section{(c) (i) (9)}

Studi Francesi è distribuita con Licenza Creative Commons Attribuzione - Non commerciale - Non opere derivate 4.0 Internazionale. 


\title{
Alain Riffaud, Répertoire dramatique du théâtre français imprimé (1630-1660)
}

\author{
Monica Pavesio
}

\section{NOTIZIA}

ALAIN RIFFAUD, Répertoire dramatique du théâtre français imprimé (1630-1660), Genève, Droz, 2009 , pp. 444.

1 Il Répertoire dramatique d'Alain Riffaud costituisce uno strumento di lavoro indispensabile per la conoscenza della produzione teatrale francese negli anni compresi tra il 1630 ed il 1660. È in questo periodo, in effetti, che all'attività creatrice dei drammaturghi si affianca quella dei librai o editori e degli stampatori, che rendono possibile la diffusione delle pièces teatrali. Si innesta dunque un processo di invenzione, produzione, fabbricazione e commercializzazione dei testi teatrali, che Riffaud ricostruisce con grande precisione.

2 Il volume, oltre a fornire l'elenco delle edizioni delle opere teatrali e la loro collocazione nelle biblioteche francesi, oltre a segnalare le riedizioni, le emissioni, le edizioni non autorizzate, le contraffazioni, svela per la prima volta i nomi e le tecniche degli stampatori parigini e di provincia che si occuparono della stampa delle opere di teatro, ricostruisce il mondo dei librai, primi editori, che finanziarono la fabbricazione dei libri, dei rilegatori e degli illustratori.

3 Il repertorio delle opere drammatiche è suddiviso per anno di edizione e presenta il nome dell'autore, il titolo, il nome dell'editore, il luogo di edizione, il formato, l'impaginazione ed il nome dello stampatore. Vengono poi indicate le biblioteche francesi dove si trovano le edizioni citate e la loro collocazione. Vi è poi una seconda tabella che presenta le edizioni apparse per la prima volta in quel dato anno, affiancata da una terza che contiene le nuove edizioni di opere già apparse precedentemente.

Alla recensione della produzione anno per anno, si aggiungono delle tavole dedicate ai drammaturghi, contenenti tutte le opere drammatiche suddivise in prime e nuove 
edizioni degli autori attivi tra il 1630 ed il 1660. Segue poi un repertorio dei titoli delle opere, segnalate in ordine alfabetico, e per finire tre repertori dedicati ai librai, i primi editori della storia, agli stampatori, con un capitolo descrittivo sui materiali utilizzati e sulle pratiche tipografiche dell'epoca, ed agli illustratori. Un ricco apparato iconografico accompagna questo volume, che si rivolge ai librai, ai collezionisti e soprattutto agli specialisti del teatro francese del XVII secolo, aprendo nuove prospettive per la ricerca sulla storia del teatro, del libro e sull'editoria francese secentesca. 